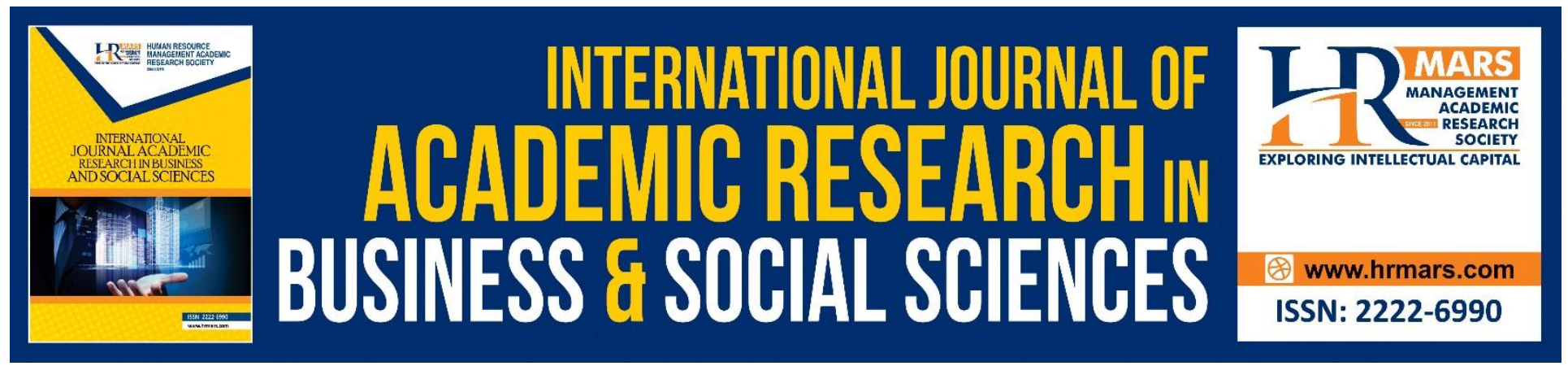

\title{
Social Support and Career Motivation in Public Service
}

\author{
Nursyamsyul Syifa Mustapa, Khairunneezam Mohd. Noor, Mahazan Abdul \\ Mutalib
}

To Link this Article: http://dx.doi.org/10.6007/IJARBSS/v9-i2/5510

DOI: $\quad 10.6007 /$ IJARBSS/v9-i2/5510

Received: 02 Feb 2019, Revised: 17 Feb 2019, Accepted: 30 Feb 2019

Published Online: 03 March 2019

In-Text Citation: (Mustapa, Noor, \& Mutalib, 2019)

To Cite this Article: Mustapa, N. S., Noor, K. M., \& Mutalib, M. A. (2019). Social Support and Career Motivation in Public Service. International Journal of Academic Research in Business and Social Sciences, 9(2), 1034-1043.

\section{Copyright: (C) 2019 The Author(s)}

Published by Human Resource Management Academic Research Society (www.hrmars.com)

This article is published under the Creative Commons Attribution (CC BY 4.0) license. Anyone may reproduce, distribute, translate and create derivative works of this article (for both commercial and non-commercial purposes), subject to full attribution to the original publication and authors. The full terms of this license may be seen

at: http://creativecommons.org/licences/by/4.0/legalcode

$$
\text { Vol. 9, No. 2, 2019, Pg. } 1034 \text { - } 1043
$$

Full Terms \& Conditions of access and use can be found at http://hrmars.com/index.php/pages/detail/publication-ethics 


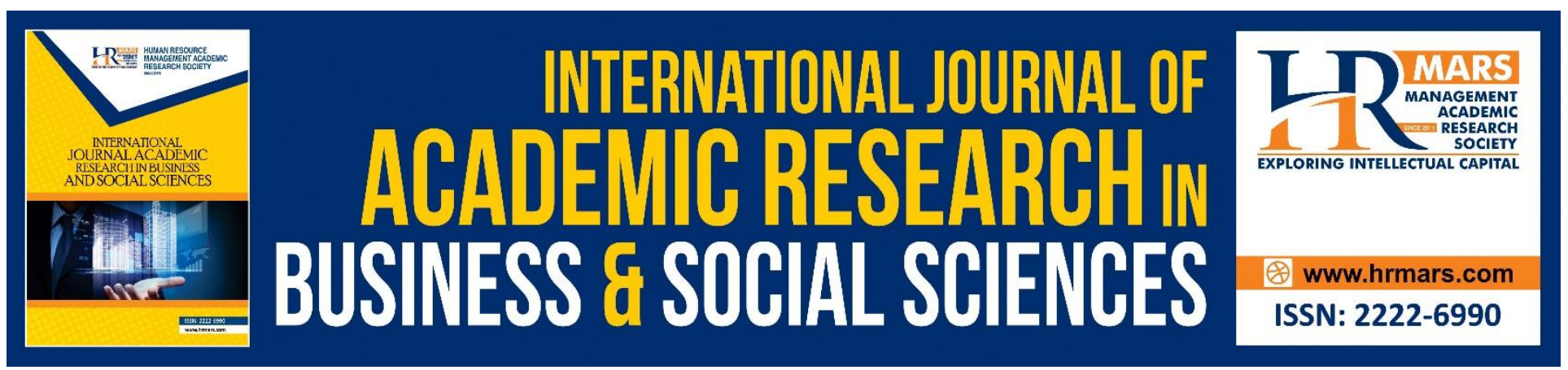

\title{
Social Support and Career Motivation in Public Service
}

\author{
Nursyamsyul Syifa Mustapa, Khairunneezam Mohd. Noor, Mahazan \\ Abdul Mutalib \\ Universiti Sains Islam Malaysia, Malaysia
}

\begin{abstract}
The quality of public service is very much depending on the motivation level of public servants. Even though career motivation is one of the important aspects of the public service, only a few studies were conducted to cover this topic. Most studies on public servants were conducted to address public service motivation rather than career motivation. Therefore, this article is an attempt to delve into the meaning of career motivation in public service as well as some common issues related to the level of career motivation among public servants. The enhancement of career motivation level could mean the major improvement of the quality of the public service. The arguments were arranged to highlight on the key findings from the previous studies that have been conducted on career motivation among public servants to serve as a contribution to the body of knowledge in the area of career motivation in human resource management in public service. The authors also investigated the role of social support on career motivation level among public servants. It was suggested from previous literature that focusing on social support could enhance career motivation among employees. To conclude, some suggestions for future studies were also conferred in this article.
\end{abstract}

Keywords: Career Motivation, Social Support, Public Service

\section{Introduction}

The quality of public service is very much depending on the motivation of the public servants (Berman, 2011). However, it was argued that the level of motivation of public servants are relatively low due to promotion to a higher grade while they are not qualified for the position (Berman, 2011). Hence, they have to remain in the public service for a long duration while waiting for retirement which resulted in low motivation level among them. Motivation formed a foundation for career development and advancement (Heimler, Rosenberg, \& Morote, 2012) but very few research focus on career motivation in public service (Berman, 2011). The importance of studying the career motivation in public service is increasing to improve the quality of public service and it is particularly important in Malaysia due to the enormous size of its public service (Kuan Heong, 2018). To understand the factors that affect motivation in public service surely is a big challenge by means of 
handling different people with different life objectives is not a simple mission (Mohammed, Khaliq, Sbaih, \& Kamil, 2014).

There are two major types of employee motivation in the public sector, namely, public sector motivation and public service motivation (Ritz, Neumann, \& Vandenabeele, 2016). Most research on public service focuses on public service motivation (Vandenabeele \& Skelcher, 2015), which highlighted the public servants' level of motivation in serving the other people or public (Mustapa \& Mahmud, 2016; Vandenabeele \& Skelcher, 2015). While public service motivation is important in the public service, public sector motivation also play the role in ensuring the sustainability and quality of public service (Salleh, Dzulkifli, Wan, \& Ariffin, 2011). Therefore, this article is attempting to highlight the importance of focusing on public service motivation particularly career motivation in public service.

\section{Career Motivation}

Motivation as a term is derived from the Latin word "movere", meaning "to move" (Mohammed et al., 2014). Zoogah (2013) defined motivation as the direction, arousal, amplitude, and persistence of an individual's behaviour. People are usually motivated by a combination of different factors and ways (Mohammed et al., 2014). Motivation is the process that arouses, energizes, directs, and sustains behaviour and performance by which it stimulates people to act and reach desired tasks through their actions. Motivation is closely related to stress and work performance of individuals (Chan, Leung, \& Liang, 2018). Managers can use motivation as a tool to stimulate factors that could push the employees towards achieving the organization's goals (Mohammed et al., 2014).

Career motivation is central to the individual and is dependent upon the individual's characteristics and environmental influences (Ortiz, 2015). The concept of career motivation applies motivation theory to understanding career plans, behaviors and decisions (London, 1993; Peters, Doorewaard, \& Eisinga, 2014). The term career motivation is associated with a wide range of career decisions and behaviors ranging from searching for a job and accepting a job, to revisiting one's career plans. Career motivation is also defined as a set of individual characteristics that are associated with career decisions and behaviors (London, 1983; Peters et al., 2014).

Career motivation is a multidimensional construct consisting of three major domains: career resilience, career insight and career identity (London, 1983). Career identity is the direction of the motivation whereby the degree that people define themselves by their work and by their organization. Career resilience is the sustainability of motivation through the ability to adapt to changing circumstances. Finally, career insight is the energizing of motivation through the realism and clarity of the individual's career goals. It involves the degree to which they immerse themselves in activities related to their job and the organization. Furthermore, motivation also can be seen through hard work, view themselves as an expert (professional or technical expert) as well as communicate pride in their organization (Alniacik, Alniacik, Kultigin, \& Erat, 2012; Mohammed et al., 2014; Zoogah, 2013). 
Motivation and performance are more important in the public sector rather than the private sector since the society is more affected by their service than the private sector. The benefit of having motivated employees could be seen from two aspects: benefit to the organization and benefit to the employee. Individuals that are motivated experience less stress, enjoy their work and have better well-being. They are also creative and innovation which in turn would benefit the organization through their contributions towards the success of the organization. Motivated employees usually have a fewer ethical problem and are more committed to the organization. The organization also would experience less employee absenteeism and turnover (Re'em, 2011).

\section{Issues in Public Sector Motivation}

The importance of career motivation can be drawn upon the overall satisfaction among the employees and this is also applicable to the public servants. Thus, the motivation and satisfaction could help the government to improve their service to the people. Despite lower pay and shortness of resources and staff, the level of motivation among public servants is particularly high because they found their work to be meaningful (Borzaga \& Tortia, 2006; Kuan Heong, 2018; Talmage, 2018). Also, the public servants' motivation reflects the way that they reacted towards human resource strategies of the public organization (London, 1988) and it was found that motivated employees are more loyal to the organization (Borzaga \& Tortia, 2006). However, a study conducted in a government department in Kedah found that the motivation level of the public servants there was mostly low (Mahazril et al., 2012) whereas another study conducted in Penang found the opposite (Che Embi et al., 2016). The contradicting findings in previous research formed a solid ground for another study to be conducted on the public servants' career motivation level. Thus, the career motivation level in public service could be questioned when only $53 \%$ of them are confident and looking forward to career development (Talmage, 2018).

Frequently, most public servants maintain their motivation to work in public service mainly because of job security (Munnell \& Cannon Fraenkel, 2013) and clearly structured pay scale (Talmage, 2018) in the government office. However, job security, as well as comfort at the office, could also mean difficulties to enhance motivation in public service due to complacency at the workplace (Re'em, 2011). Public service employees suffer from low morale and motivation due to the negative image of the government and its community painted by the media as well as politicians (Lavigna, 2014). Public workers have a reputation for being lazy and lethargic (Re'em, 2011), low efficiency (Raudeliūnienè \& Meidutè-Kavaliauskienè, 2014), ageing and plateauing public sector (Lavigna, 2014). Sometimes, public servants are also perceived as overpaid and underworked (Lavigna, 2014) who are hard to motivate (Re'em, 2011). Due to rigid civil-service laws, there is limited opportunity to manoeuvre the motivation level (Lavigna, 2014; Re'em, 2011). Other challenges to motivate public servants such as frequent and abrupt changes of leaders make it hard to measure the achievement of public servants (Lavigna, 2014).

Some researcher alleged that employees are commonly motivated by extrinsic motives rather than intrinsic motives (Re'em, 2011). However, it was believed that public service employees are motivated by different sets of motives among others their commitment to governments agenda to 
INTERNATIONAL JOURNAL OF ACADEMIC RESEARCH IN BUSINESS AND SOCIAL SCIENCES

Vol. 9, No. 2, Feb, 2019, E-ISSN: $2222-6990$ ๑ 2019 HRMARS

serve the public (Lavigna, 2014). Monetary rewards, pay-for-performance or bonuses will be less influential on the motivation of public sector workers than private sector employees (Rashid \& Rashid, 2012). Public sector employees are more motivated by work contents and experience more balance between work and family life (Rashid \& Rashid, 2012). Public sector employees are also more attracted to intrinsic motivation rather than extrinsic motivation (Georgellis, lossa, \& Tabvuma, 2011).

\section{How Social Support Affect Career Motivation}

The definition of social support is always being criticized for its variety and vagueness (Ortiz, 2015; Sarwar \& Khalid, 2015). Frequently, social support refers to the amount of value that an individual believes he or she will receive from their social interactions (Ortiz, 2015) and the degree to which employees perceive their support system (family, friends, supervisors and co-workers) care about their well-being as well as respecting their contributions (Simosi, 2012). The support can be offered by providing practical (such as assisting in managing daily household's operations) or emotional support (such as giving advice) (Achour, Mohd Yusoff, \& Mohd Nor, 2013; Nasurdin \& O'Driscoll, 2011; Russo, Shteigman, \& Carmeli, 2015). Work and family social support is vital to unleash positive energy among employees (Russo et al., 2015).

Russo et al. (2015) in their study investigated two types of support namely; workplace support and family support. Workplace social support is defined as "the degree to which individuals perceive that their well-being is valued by workplace sources... and the perception that these sources provide help to support this well-being" which includes support from the organisation and its members, i.e. the organisation itself, supervisor and co-workers (Kossek, Pichler, Bodner, \& Hammer, 2011). Family support refers to support that acquired from family members or family unit such as spouse, parents, siblings, children as well as extended family. Both workplace and family social support can be instrumental (such as tangible help offered by the sources) and emotional (such as actions by sources that make the recipient feel that they are taken care of) (Russo et al., 2015). There are also studies that focus on social support from the perspective of different culture such as wasta in the Arab culture (Abalkhail \& Allan, 2015, 2016; Afiouni, 2014; Omair, 2010; Said, Rasdi, Samah, Silong, \& Sulaiman, 2015; Tlaiss, 2015; Tlaiss \& Kauser, 2011) and guanxi in the Chinese culture (Kashif, Zarkada, \& Thurasamy, 2017; Millar \& Culpin, 2014; Napasri \& Yukongdi, 2015; Tlaiss \& Kauser, 2010).

London (1993) stressed that career behavior and decision making should be steered by the amount of support and guidance provided by the environment. Frequently, employee performance and productivity are strengthened by support from supervisors and co-workers in managing work, personal and family life (Kim \& Wiggins, 2011). The employees that have support from supervisors and co-workers usually experience life satisfaction. In a study conducted among students, both motivational characteristics and perceived social support from family and friends were shown to be highly contribute to academic outcomes (Ortiz, 2015) and support from others (i.e., parents, siblings, and teachers) significantly influenced both intrinsic and extrinsic motivation (Vatankhah \& Tanbakooei, 2014).. Other studies also showed that there was a positive correlation amongst the 
levels of external motivation, internal motivation, and motivation for the subject value of the individuals who received sufficient social support from their environment (Noe, Noe, \& Bachhuber, 1990; Tezci, Sezer, Gurgan, \& Aktan, 2015).

London (1983) stated that the components of career motivation such as career insight and career resilience should be related to the amount of support and guidance provided by the organization (London, 1983). Another study also indicated that social resources (i.e. social support) are one of the critical career resources which are essential for career development (Hirschi, 2012).

Social support also enhances intrinsic motivation (Mas-Machuca, Berbegal-Mirabent, \& Alegre, 2016; Van Yperen \& Hagedoorn, 2003) and social support is the most effective way to enhance intrinsic motivation (Van Yperen \& Hagedoorn, 2003). Social support is also recognized as one of four critical factors of career resources (Hirschi, 2012) for career self-management. Sarwar and Khalid (2015) found that there was a significant positive relationship between social support and work motivation. Having the people around to provide support will provide more opportunities in a career because resources do not generally exist in isolation but work in a collective way (Hirschi, 2012). For young people in Malaysia, parents have most influenced career choice (Kuan Heong, 2018) thus this could also affect career motivation. The significant relationship between social support and career motivation suggests that organizations need to train managers to ensure that they have competence in the interpersonal roles necessary to facilitate and maintain employees' career motivation (Noe et al., 1990). Employees with supportive managers and organization feel more confident and positive and likely to view their workplaces as favourable (Alniacik et al., 2012; Shuck, Peyton Roberts, \& Zigarmi, 2018). Similarly, social support increases the motivation level of employee to learn to improve performance (Karami, Ismail, Omar, Abdul Wahat, \& Badsar, 2012; Ng \& Ahmad, 2016).

\section{Conclusion}

There are many issues and challenges that are faced by managers in public service in motivating public servants. However, with limited studies conducted in career motivation among public servants, some of the issues and challenges remain unanswered. Previous studies had proved that workplace social support can enhance the motivation level of employees. Nevertheless, not many researches focused on social support from family members and friends as related to career motivation. There is evidence that family and friends support contributed to a higher motivation level among students, but it cannot be claimed the same for the working adults due to lack of evidence. Therefore, it is suggested that more research is conducted to study the effect of social support from family and friends on career motivation, particularly in public service.

\section{Acknowledgement}

The authors would like to thank the Public Service Department of Malaysia for its support in conducting this research. 
INTERNATIONAL JOURNAL OF ACADEMIC RESEARCH IN BUSINESS AND SOCIAL SCIENCES

Vol. 9, No. 2, Feb, 2019, E-ISSN: 2222-6990 C 2019 HRMARS

\section{Corresponding Author}

Nursyamsyul Syifa Mustapa, Islamic Science University of Malaysia, Malaysia. E-mail:

syifamustapa@gmail.com

\section{References}

Abalkhail, J. M., \& Allan, B. (2015). Women's career advancement : mentoring and networking in Saudi Arabia and the UK. Human Resource Development International, 18(2), 153-168.

Abalkhail, J. M., \& Allan, B. (2016). "Wasta" and women's careers in the Arab Gulf States. Gender in Management: An International Journal, 31(3), 162-180. Retrieved from http://dx.doi.org/10.1108/GM-02-2015-0006

Achour, M., Mohd Yusoff, M. Y. Z., \& Mohd Nor, M. R. (2013). Moderating Effects of Supervisory Support between Work-Family Demands and Life Satisfaction among Malaysian Female Academicians. In Proceedings Book of ICEFMO (pp. 564-572).

Afiouni, F. (2014). Women's careers in the Arab Middle East: understanding institutional constraints to the boundaryless career view. Career Development International, 19(3), 4. https://doi.org/10.1108/CDI-05-2013-0061

Alniacik, U., Alniacik, E., Kultigin, A., \& Erat, S. (2012). Relationships between career motivation , affective commitment and job satisfaction. Procedia - Social and Behavioral Sciences, 58, 355362. https://doi.org/10.1016/j.sbspro.2012.09.1011

Berman, E. M. (Ed.). (2011). Public Administration in Southeast Asia: Thailand, Philippines, Malaysia, Hong Kong and Macao. Taylor and Francis Group. Florida, USA: CRC Press.

Borzaga, C., \& Tortia, E. (2006). Worker motivations, job satisfaction, and loyalty in public and nonprofit social services. Nonprofit and Voluntary Sector Quarterly, 35(2), 225-248. https://doi.org/10.1177/0899764006287207

Chan, I. Y. S., Leung, M. Y., \& Liang, Q. (2018). The roles of motivation and coping behaviours in managing stress: Qualitative interview study of Hong Kong expatriate construction professionals in mainland China. International Journal of Environmental Research and Public Health, 15(3). https://doi.org/10.3390/ijerph15030561

Che Embi, M. S., Romle, A. R., Mohd Udin, M., Mohamad Zabri, M. A. H., Mohd Zahid, S. Z., \& Mat Isa, N. H. (2016). The Level of Motivation Amongst Public Service Servant in Penang Malaysia. World Applied Sciences Journal, 34(4), 458-464. https://doi.org/10.5829/idosi.wasj.2016.34.4.15681

Georgellis, Y., lossa, E., \& Tabvuma, V. (2011). Crowding out intrinsic motivation in the public sector. Journal of Public Administration Research and Theory, 21(3), 473-493. https://doi.org/10.1093/jopart/muq073

Heimler, R., Rosenberg, S., \& Morote, E.-S. E. E.-S. E. (2012). Predicting career advancement with structural equation modelling. Education + Training, 54(2/3), 85-94.

https://doi.org/10.1108/00400911211210215 
INTERNATIONAL JOURNAL OF ACADEMIC RESEARCH IN BUSINESS AND SOCIAL SCIENCES

Vol. 9, No. 2, Feb, 2019, E-ISSN: $2222-6990$ ๑ 2019 HRMARS

Hirschi, A. (2012). The career resources model : an integrative framework for career counsellors, 40(4), 369-384.

Karami, R., Ismail, M., Omar, Z., Abdul Wahat, N. W., \& Badsar, M. (2012). Organizational Support and Achievement Motivation in Leadership Role of Extension Agents. American Journal of Applied Sciences, 9(5), 633-640.

Kashif, M., Zarkada, A., \& Thurasamy, R. (2017). The moderating effect of religiosity on ethical behavioural intentions: An application of the extended theory of planned behaviour to Pakistani bank employees. Personnel Review, 46(2), 429-448. https://doi.org/10.1108/

Kim, J., \& Wiggins, M. E. (2011). Family-Friendly Human Resource Policy: Is It Still Working in the Public Sector? Public Administration Review, 71(5), 728-739. https://doi.org/10.1111/j.15406210.2011.02412.x

Kossek, E. E., Pichler, S., Bodner, T., \& Hammer, L. B. (2011). Workplace Social Support and Work Family Conflict: A Meta-Analysis Clarifying the Influence of General and Work - Family-Specific Supervisor and Organizational Support. Personnel Psychology, 64, 289-313. Retrieved from http://www.kpchr.org/workplacenetwork/.

Kuan Heong, W. (2018). Public Employment: Attractiveness, Representativeness, and Performance. International Journal of Public Administration, 41(8), 604-618. https://doi.org/10.1080/01900692.2017.1292284

Lavigna, R. (2014, November). Why Government Workers Are Harder to Motivate. Harvard Business Review, 5. Retrieved from https://hbr.org/2014/11/why-government-workers-are-harder-tomotivate

London, M. (1983). Toward a Theory of Career Motivation. Academy of Management Review, 8(4), 620-630. https://doi.org/10.5465/AMR.1983.4284664

London, M. (1988). Organizational Support for Employees' Career Motivation : A Guide to Human Resource Strategies in Changing Business Conditions. Human Resource Planning, 11(1), $23-32$.

London, M. (1993). Relationships between Career Motivation, Empowerment and Support, (1 993).

Mahazril, A. Y., Zuraini, Y. Z., Hafizah, H. A. K., Aminuddin, A., Zakaria, Z., Noordin, N., \& Mohamed, B. A. (2012). Work motivation among Malaysian public servants. Asian Social Science, 8(12), 238-242. https://doi.org/10.5539/ass.v8n12p238

Mas-Machuca, M., Berbegal-Mirabent, J., \& Alegre, I. (2016). Work-life balance and its relationship with organizational pride and job satisfaction. Journal of Managerial Psychology, 31(2), 586602. https://doi.org/10.1108/JMP-09-2014-0272

Millar, C. C. J. M., \& Culpin, V. (2014). AGE-ility challenges, and management agendas for the organisation. Journal of Organizational Change Management, 27(4), 542-549. Retrieved from http://dx.doi.org/10.1108/JOCM-05-2014-0099

Mohammed, S., Khaliq, A., Sbaih, B., \& Mohammed Kamil, N. (2014). The perspective of Muslim employees towards motivation and career success. Journal of Social Sciences and Humanities, 
INTERNATIONAL JOURNAL OF ACADEMIC RESEARCH IN BUSINESS AND SOCIAL SCIENCES

Vol. 9, No. 2, Feb, 2019, E-ISSN: $2222-6990$ ๑ 2019 HRMARS

9(1), 45-62.

Munnell, A. H., \& Cannon Fraenkel, R. (2013). Public Sector Workers and Job Security, (31).

Retrieved from http://crr.bc.edu/wp-content/uploads/2013/05/SLP31.pdf

Mustapa, A. N., \& Mahmud, R. (2016). The Effects of Public Service Motivation on Job Performance : Myth or Reality ? Journal of Management Studies, 2(7), 144-164.

Napasri, T., \& Yukongdi, V. (2015). A Study of Thai Female Executives: Perceived Barriers to Career Advancement. Rev. Integr. Bus. Econ. Res., 4(3), 108-120.

Nasurdin, A. M., \& O’Driscoll, M. P. (2011). Work Overload , Parental Demand , Perceived Organizational Support , Family Support , and Work-Family Conflict among New Zealand and Malaysian Academics. New Zealand Journal of Psychology, 40(3), 38-48.

Ng, K. H., \& Ahmad, R. (2016). Personality traits, social support, and training transfer: the mediating mechanism of motivation to improve work through learning. Personnel Review. https://doi.org/10.1108/09574090910954864

Noe, A., Noe, A. N. N. W., \& Bachhuber, J. A. (1990). An Investigation of the Correlates of Career Motivation. Journal of Vocational Behavior, 37, 340-356.

Omair, K. (2010). Typology of career development for Arab women managers in the United Arab Emirates. Career Development International, 15(2), 121-143. Retrieved from http://dx.doi.org/10.1108/13620431011040932

Ortiz, R. E. (2015). Exploring the relationship between social support and career motivation for minority women. San Francisco State University.

Peters, P., Doorewaard, H., \& Eisinga, R. (2014). Supporting 'superwomen'? Conflicting role prescriptions, gender-equality arrangements and career motivation among Dutch women physicians. Human Relations, 67(2), 175-204. https://doi.org/10.1177/0018726713489998

Rashid, S., \& Rashid, U. (2012). Work Motivation Differences between Public and Private Sector. American International Journal of Social Science, 1(2), 24-33. https://doi.org/doi: 10.1111/cge.12749

Raudeliūnienè, J., \& Meidutè-Kavaliauskienè, I. (2014). Analysis of Factors Motivating Human Resources in Public Sector. Procedia - Social and Behavioral Sciences, 110, 719-726. https://doi.org/10.1016/j.sbspro.2013.12.916

Re'em, Y. (2011). Motivating public sector employees: An application-oriented analysis of possibilities and practical tools.

Ritz, A., Neumann, O., \& Vandenabeele, W. (2016). Chapter 30: Motivation in the Public Sector. In The Routledge Handbook of Global Public Policy and Administration.

Russo, M., Shteigman, A., \& Carmeli, A. (2015). Workplace and family support and work - life balance : Implications for individual psychological availability and energy at work. The Journal of Positive Psychology, 173-188. https://doi.org/10.1080/17439760.2015.1025424 
INTERNATIONAL JOURNAL OF ACADEMIC RESEARCH IN BUSINESS AND SOCIAL SCIENCES

Vol. 9, No. 2, Feb, 2019, E-ISSN: $2222-6990$ ๑ 2019 HRMARS

Said, A.-M. A., Rasdi, R. M., Samah, B. A., Silong, A. D., \& Sulaiman, S. (2015). A career success model for academics at Malaysian research universities. European Journal of Training and Development, 39(9), 815-835. https://doi.org/10.1108/EJTD-03-2015-0022

Salleh, F., Dzulkifli, Z., Wan Abdullah, W. A., \& Ariffin, N. H. M. Y. @. (2011). The Effect of Motivation on Job Performance of State Government Employees in Malaysia. International Journal of Humanities and Social Science, 1(4), 147-154. https://doi.org/10.1093/nq/186.2.42

Sarwar, A., \& Khalid, S. (2015). Perceived social support and work motivation of day and night shift nurses. Pakistan Armed Forces Medical Journal, 65(2), 257-261. Retrieved from https://search.proquest.com/docview/1686090170?accountid=17242

Shuck, B., Peyton Roberts, T., \& Zigarmi, D. (2018). Employee Perceptions of the Work Environment, Motivational Outlooks, and Employee Work Intentions: An HR Practitioner's Dream or Nightmare? Advances in Developing Human Resources, 20(2), 197-213. https://doi.org/10.1177/1523422318757209

Simosi, M. (2012). Disentangling organizational support construct. Personnel Review, 41(3), 301320. https://doi.org/10.1108/00483481211212959

Talmage, L. (2018). The highs and lows of working in the public sector.

Tezci, E., Sezer, F., Gurgan, U., \& Aktan, S. (2015). A study on social support and motivation. Anthropologist, 22(2), 284-292. https://doi.org/10.1080/09720073.2015.11891879

Tlaiss, H. (2015). Neither-nor: career success of women in an Arab Middle Eastern context. Employee Relations, 37(5), 525-546.

Tlaiss, H., \& Kauser, S. (2010). Perceived organizational barriers to women's career advancement in Lebanon. Gender in Management: An International Journal, 25(6), 462-496.

Tlaiss, H., \& Kauser, S. (2011). The impact of gender, family, and work on the career advancement of Lebanese women managers. Gender in Management: An International Journal, 26(1), 8-36.

Van Yperen, N. W., \& Hagedoorn, M. (2003). Do high job demands increase intrinsic motivation or fatigue or both? The role of job control and job social support. Academy of Management Journal, 46(3), 339-348. https://doi.org/10.2307/30040627

Vandenabeele, W., \& Skelcher, C. (2015). Review: Public service motivation-practical problems, scientific evidence and the role of a research community. Public Money and Management, 35(5), 321-327. https://doi.org/10.1080/09540962.2015.1061165

Vatankhah, M., \& Tanbakooei, N. (2014). The Role of Social Support on Intrinsic and Extrinsic Motivation among Iranian EFL Learners. In Procedia - Social and Behavioral Sciences (Vol. 98, pp. 1912-1918). Elsevier B.V. https://doi.org/10.1016/j.sbspro.2014.03.622

Zoogah, D. B. (2013). Career Motivation, Mentoring Readiness, and Participation in Workplace Mentoring Programs: A Cross-Cultural Study. Journal of African Business, 14(1), 19-32. https://doi.org/10.1080/15228916.2013.765310 